\title{
AÇÃO DE RESSARCIMENTO AO ERÁRIO POR ATO DOLOSO DE IMPROBIDADE E O CONDICIONAMENTO DA PRESCRIÇÃO À SUBJETIVIDADE DO AGENTE
}

\section{ACTION OF REIMBURSEMENT TO THE ERATION FOR ATO DOLOSO OF IMPROBITY AND THE CONDITIONING OF THE PRESCRIPTION TO AGENT SUBJECTIVITY}

\author{
Emerson Gabardo ${ }^{1}$ \\ Rodrigo Pavan de Valões ${ }^{1}$
}

Recebido em: 30/08/2020 Aceito em: 10/11/2021

emerson.gabardo.br@gmail.com rrodrigovaloes@gmail.com
Resumo: O presente estudo analisa o entendimento adotado pelo Supremo Tribunal Federal ao julgar imprescritíveis as ações de ressarcimento ao erário nos casos de improbidade administrativa, a partir da interpretação do art. 37, § 5ㅇ, da Constituição Federal. Em um primeiro momento, é feita uma análise doutrinária acerca da compreensão do dispositivo, contrapondo a decisão da Suprema Corte a princípios basilares do Estado Democrático de Direito, bem como à noção de que a regra do sistema jurídico é a prescrição, enquanto a imprescritibilidade é a exceção, devendo ser prevista expressa e taxativamente. Na sequência, apresenta-se que a imprescritibilidade, no plano material, acaba por configurar-se como uma sanção àquele que cometeu ato de improbidade. $\mathrm{Na}$ parte final do artigo, após a exposição da prescrição enquanto instituto destinado à segurança das relações jurídicas, o estudo conclui que a decisão do STF a respeito da matéria é equivocada, sobretudo quando desnatura a prescrição, que deixa de ser uma prejudicial da análise do mérito e passa a ser a ele condicionada - o que ocasiona uma afronta ao direito fundamental à ampla defesa.

Palavras-chave: Dano ao erário; Ação de ressarcimento; Imprescritibilidade; Improbidade administrativa; Prejudicial da análise de mérito.

\begin{abstract}
The present study analyzes the understanding adopted by the Brazilian Federal Supreme Court in judging that there is no limitation period for filling a case of compensation of damages to the treasury in situations of administrative dishonesty, based on the interpretation of art. $37, \S 5^{\circ}$, of the Federal Constitution. At first, a doctrinal analysis is made about the understanding of the clause, opposing the decision of the Supreme Court to basic principles of the Democratic Rule of Law, as well as the notion that the rule of the legal system is the statute of limitations, while imprescriptibility is an exception and must be foreseen expressly and exhaustively. Subsequently, it is presented that the imprescriptibility, materially, ends up being a sanction to the one who committed the act of improbity. In the final part of the article, after exposing the prescription as an institute for the certainty of legal relations, the study concludes that the STF's decision regarding the matter is wrong, especially when it denatures the prescription, which is no longer harmful to the analysis of the merit and becomes conditioned to it - which causes an affront to the fundamental right to ample defense.
\end{abstract}

Keywords: Damage to the treasury; Compensation action; Imprescriptibility; Administrative dishonesty; Detrimental to the analysis of merit.

\footnotetext{
${ }^{1}$ Pontifícia Universidade Católica do Paraná e Universidade Federal do Paraná - Paraná - Brasil
} 


\section{INTRODUÇÃO}

A prescritibilidade ou não das ações de ressarcimento ao erário em razão dos danos causados por ato de improbidade sempre proporcionou discussão, seja no âmbito da doutrina, seja no âmbito da jurisprudência. Quando instado a manifestar-se, o Supremo Tribunal Federal reconheceu a repercussão geral da questão discutida no Recurso Extraordinário 852.475/SP.

O que não se esperava, porém, era que, ao decidir a questão, fosse fixado entendimento divergente das discussões tidas quando do julgamento do RE 669.069, que julgou prescritíveis as ações de ressarcimento ao erário em virtude de danos causados por ilícitos civis. E mais, adotando interpretação não presente no ordenamento jurídico. Não bastando entender pela imprescritibilidade, o STF o fez afirmando que serão imprescritíveis somente as ações de ressarcimento fundadas em atos dolosos de improbidade. Ou seja, condicionou o reconhecimento da prescrição à análise do mérito, de modo a subverter toda a lógica desse instituto, que é a de assegurar a segurança jurídica das relações travadas no campo social.

Desta maneira, tomando como hipótese a discordância com os rumos tomados pela Suprema Corte, propõe-se, após uma breve exposição de como foi o julgamento, à realização de uma análise do que dispõe a doutrina acerca do art. 37, § 5º, da Constituição Federal, bem como da evolução histórica da redação do dispositivo. Assim, partindo do núcleo das controvérsias, buscar-seá responder à seguinte questão: a tese fixada pelo Supremo contraria a Constituição?

A metodologia utilizada é a teórico-descritiva. Com o uso do método dedutivo serão analisadas a doutrina e a jurisprudência relevante na matéria. Parte-se do pressuposto que a analítica e a hermenêutica são duas faces da mesma moeda na solução dos conflitos interpretativos - conflitos estes que devem ser resolvidos a partir da busca pela racionalidade da decisão. Como afirmam Américo Bedê Freire Júnior e Willy Potrich da Silva (2019, p. 60), aumenta a relevância da aproximação entre as ideias de "descoberta e justificação" quando as decisões do Supremo Tribunal Federal, "sob o pretexto de guarda da Constituição, mostram-se como verdadeiras inovações legislativas levadas a efeito por um órgão essencialmente não democrático".

A tratativa do tema busca fugir de dicotomias tais como entre interesse público e direitos fundamentais, garantismo e punitivismo ou mesmo entre direitos fundamentais e reserva do possível (ainda que talvez esteja por detrás da decisão do STF a prevalência de um interesse público distorcido, uma punitivismo exacerbado e uma visão consequencialista do Direito). ${ }^{2}$ Devido ao seu recorte metodológico, o presente ensaio estará dedicado à demonstração dogmática da prescrição como asseguradora da segurança jurídica e obstativa de pretensões processuais. Partindo destas premissas e da lógica implantada pelo STF, será exposto criticamente como a prescrição deixa de ser uma prejudicial da análise do mérito do caso, tornando-se uma decorrência deste; e que, em algumas situações, sequer será aplicada ao longo da marcha processual. Fatores estes que contribuem para o abandono da racionalidade da decisão - o que é ruim para o sistema como um todo.

2 Para além do "binarismo", que talvez poderia ser útil em outras análises, o texto parte da premissa que a decisão do STF acaba por limitar inadequadamente o modelo de Estado social de Direito estabelecido pela Constituição. No mesmo sentido, ainda que tratando especificamente a deturpação do instituto da "reserva do possível", ver CASTRO e ZUCCHI, 2019. 


\section{QUE FOI DECIDIDO NO RE 852.475/SP?}

"São imprescritíveis as ações de ressarcimento ao erário fundadas na prática de ato doloso tipificado na Lei de Improbidade Administrativa". Foi esta a tese fixada pelo Supremo Tribunal Federal quando da conclusão do julgamento do Recurso Extraordinário 852.475/SP, leading case do Tema 897 da Repercussão Geral (Prescritibilidade da pretensão de ressarcimento ao erário em face de agentes públicos por ato de improbidade administrativa).

Tratava-se de recurso extraordinário interposto pelo Ministério Público do Estado de São Paulo (MP-SP), em ação de improbidade administrativa que apurava a participação de servidores públicos em suposto ato de improbidade causador de danos ao erário (venda de veículos que, até então, compunham o patrimônio público). No recurso, o MP-SP pleiteou a aplicação aos réus das sanções previstas na Lei de Improbidade Administrativa (Lei 8.429/1992), bem como o ressarcimento do dano causado pela alienação dos veículos abaixo do valor de mercado.

A venda dos veículos havia ocorrido no ano de 1995. A ação civil pública, por sua vez, foi proposta somente em 2001. Após recurso de apelação apresentado pelos réus, o Tribunal de Justiça do Estado de São Paulo julgou extinta a ação ante a prescrição das sanções de improbidade e, por consequência, do pedido de ressarcimento.

Inconformado com a decisão, o MP-SP protocolou apelo extraordinário, sustentando que os pedidos de ressarcimento são imprescritíveis, por força do que dispõe $\circ \S 55^{\circ}$, do art. 37 , da Constituição Federal. Requereu, então, o provimento do recurso extraordinário para que fosse reformado o acórdão, afastando-se a extinção do processo pelo reconhecimento da prescrição ou, no mínimo, o afastamento da declaração de prescrição da pretensão de ressarcimento do dano. A Procuradoria-Geral da República manifestou-se pelo parcial provimento do apelo extraordinário, para que fosse reconhecida a imprescritibilidade somente no que tange ao ressarcimento ao erário.

Na primeira assentada, que ocorreu em 02.08.2018, o Min. Alexandre de Moraes, relator do recurso, votou pelo desprovimento do recurso. Para tanto, o Ministro baseou-se na observância ao devido processo legal, garantia fundamental posta pelo Texto Constitucional, a qual, se descumprida, acarreta violação aos direitos de defesa e do contraditório do jurisdicionado. Assim, e em fidelidade à segurança jurídica, o relator defendeu que o ordenamento jurídico pátrio afasta a imprescritibilidade das ações ressarcitórias, de modo que a pretensão de ressarcimento ao erário em decorrência da prática de atos de improbidade administrativa (previstos pela Lei 8.429/92) "prescreve juntamente com as demais sanções do art. 12 , nos termos do art. 23 , ambos da referida lei, sendo que, na hipótese em que a conduta também for tipificada como crime, os prazos prescricionais são os estabelecidos na lei penal" (STF, 2018).

Na mesma sessão, o ministro Luiz Edson Fachin inaugurou divergência e votou pela imprescritibilidade do pedido de ressarcimento. De acordo com o Min. Fachin, o § 5ㄴ, do artigo 37 , faria parte do rol de exceções explícitas da Constituição à regra da prescritibilidade. A ressalva, ao retirar as ações de ressarcimento do comando inicial do dispositivo, tornaria imprescritíveis tais ações. Portanto, para o Ministro, seriam imprescritíveis as ações de ressarcimento ao erário fundadas na prática de ato de improbidade administrativa, pois "o texto constitucional é expresso ao prever que 
a lei estabelecerá os prazos de prescrição para ilícitos", mas que, logo em seguida, "decota de tal comando para o Legislador as ações cíveis de ressarcimento (ou seja, de recomposição) do erário, tornando-as, assim, imprescritíveis."

A primeira parte do julgamento terminou com maioria formada para desprover o recurso do MP-SP, reconhecendo a prescritibilidade da ação de ressarcimento ao erário por ato de improbidade administrativa. Na ocasião, o relator Min. Alexandre de Moraes foi acompanhado pelos ministros Luís Roberto Barroso, Luiz Fux, Dias Toffoli, Ricardo Lewandowski e Gilmar Mendes. Aderiu à divergência, pela imprescritibilidade das ações de recomposição, apenas a Ministra Rosa Weber.

$\mathrm{Na}$ segunda reunião dos ministros para julgar o caso, em 08.08.2018, o Min. Marco Aurélio acompanhou o voto do relator, reconhecendo, também, a prescritibilidade das ações de ressarcimento fundadas em ato tipificado como improbidade administrativa. O Ministro Celso de Mello e a Ministra Carmen Lúcia votaram pela imprescritibilidade. Nesta mesma sessão, os ministros Luiz Fux e Luís Roberto Barroso reajustaram seus votos para acompanhar a divergência inaugurada pelo Min. Fachin.

Barroso reajustou seu voto para acompanhar a divergência. Contudo, restringindo a imprescritibilidade das ações de ressarcimento ao erário às hipóteses de improbidade administrativa dolosa. Fux, que já havia revisto seu posicionamento, aderiu à tese de Barroso, que sugeriu a Fachin a readequação da tese, de modo a restringir a imprescritibilidade das ações de ressarcimento para as ações fundadas em atos dolosos de improbidade administrativa.

Assim, após farta discussão, finalmente fixou-se a tese da imprescritibilidade das ações de ressarcimento ao erário por ato doloso de improbidade administrativa. Ou seja, ao decidir sobre o alcance do dispositivo constitucional, o STF entendeu que serão imprescritíveis as ações de ressarcimento, quando objetivarem a recomposição do erário pelos danos causados por atos de improbidade dolosos. Sobre a reparação dos danos causados por condutas culposas de improbidade, por sua vez, não incidirá a imprescritibilidade.

É possível apontar que a conclusão atingida pelo STF é a seguinte: o $§ 5^{\circ}$, do art. 37 , da Constituição Federal, afirma que as ações de ressarcimento serão imprescritíveis, desde que o dano tenha sido causado por um ato doloso de improbidade. A hipótese sustentada no presente trabalho assevera que a concussão do STF é equivocada pois: $1^{\circ}$ ) não é possível extrair tal conclusão do texto constitucional, que não admite solução diversa da dicotomia entre prescritibilidade ou imprescritibilidade, para a totalidade dos atos de improbidade - sem distinção; $2^{\circ}$ ) a imprescritibilidade dos atos de improbidade não coaduna com o ordenamento jurídico constitucional, que garante a regra geral da prescritibilidade para todos os casos de ressarcimento.

Portanto, além de adotar uma interpretação que viola o princípio da segurança jurídica, essencial para a estabilidade das relações sociais, o STF acaba por inovar no ordenamento, pois condiciona a incidência do instituto da prescrição à aferição da conduta dolosa ou culposa do agente - que ocorrerá, na maioria dos casos, apenas quando da prolação da sentença -, desvirtuando a sua função processual enquanto uma prejudicial da análise do mérito e óbice à pretensão deduzida pelo autor. 


\section{AS AÇÕES DE RESSARCIMENTO AO ERÁRIO NÃO SÃO IMPRESCRITÍVEIS}

Ressalvar as ações de ressarcimento da lei que estabelecerá os prazos de prescrição para os ilícitos praticados por agentes, servidores ou não, que causem prejuízos ao erário - este é o comando constitucional descrito pelo $\S 5^{\circ}$, do artigo 37 , da $\mathrm{CF} / 88$ que causa muitas dúvidas ao operador do Direito desde a sua promulgação.

Tão logo publicado o texto final da Constituição, a doutrina inaugurou divergência sobre o alcance do dispositivo, razão pela qual logo foi possível verificar posicionamentos para ambos os lados. Comentando o recém promulgado dispositivo, Celso Ribeiro Bastos e Ives Gandra Martins (1992) - por mais que tenham lamentado pela decisão tomada pelo constituinte - afirmaram que o texto constitucional estava a consagrar exceção à regra da prescritibilidade, ou seja, que são imprescritíveis as ações de ressarcimento. Sergio de Andréa Ferreira (1991), por sua vez, pregou que o texto final da Carta Magna não desejou, em momento algum, a imprescritibilidade das ações de ressarcimento ao erário por danos causados por atos de improbidade.

Não foram poucas as discussões acerca da interpretação a ser conferida ao dispositivo, doutrinária e jurisprudencialmente. Tanto é assim que foram quase mil casos afetados pelo reconhecimento da repercussão geral do assunto pelo Supremo Tribunal Federal. É impossível deixar de reconhecer que a redação do parágrafo em discussão é dúbia.

Por outro lado, a interpretação proposta pelo Ministro Luiz Edson Fachin, e pela doutrina considerada majoritária no assunto, ${ }^{3}$ acaba perdendo amplitude, uma vez que é meramente "literal" (GUSSOLI, 2015, p. 261). Para que se atinja a real intenção da norma, deve ser realizada uma exegese sistemática do dispositivo a partir das diretrizes fundamentais do Texto Constitucional, em especial a proposta de um Estado Democrático de Direito. Afinal, o Direito não pode ser interpretado em tiras, isoladamente, devendo ser compreendido no seu todo. ${ }^{4}$

Desta maneira, a partir de uma análise sistemática do texto constitucional, é possível chegar à conclusão de que a prescritibilidade é a regra do ordenamento. A imprescritibilidade, portanto, é a exceção. E, por ser a exceção à regra, além de demandar uma leitura restritiva, estando vedada a criação de situações de imprescritibilidade mediante analogia, ${ }^{5}$ só pode ser admitida nos casos em que estiver expressa, taxativa e inequivocamente prevista no texto constitucional (BARROSO, 2001,

\footnotetext{
$3 \quad$ Aqui, cita-se como exemplo do posicionamento tido como majoritário o entendimento de Pedro Roberto Decomain: "Mas as ações de ressarcimento de danos ao Erário foram tornadas imprescritíveis pelo mencionado parágrafo 5으 do art. 37 da Constituição Federal, a despeito de algumas críticas dirigidas àquele dispositivo. A redação do parágrafo em apreço, todavia, não deixa margem para dúvida. Há nele [art. 37, 5] dois comandos, ambos dirigidos ao legislador ordinário. $O$ primeiro lhe ordena: estabeleça prazo de prescrição para punições aplicáveis a agentes públicos pela prática de atos que causem prejuízo ao Erário. É o que consta da primeira parte do parágrafo. Já o segundo comando impõe: não estabeleça prazo para prescrição da pretensão de ressarcimento dos danos que o ilícito haja imposto ao Erário. Como se vê, exatamente o inverso do primeiro. (...) Muito ao inverso, porém o que do dispositivo consta é, na segunda parte, uma expressa ressalva à incidência do comando contido na primeira." (DECOMAIN, 2014, p. 467). No mesmo sentido, é a posição de José dos Santos Carvalho Filho (2016, p. 246-247).

"A interpretação do direito é interpretação do direito, no seu todo, não de textos isolados, desprendidos do direito. Não se interpreta o direito em tiras, aos pedaços. (...) Um texto de direito isolado, destacado, desprendido do sistema jurídico, não expressa significado normativo algum"; (GRAU, 2009, p. 44).

$5 \quad$ O principal autor a sustentar a impossibilidade de analogia nestes casos é Romeu Felipe Bacellar Filho (2013, p. 455 e ss.). No mesmo sentido, pode-se mencionar a doutrina de Antonio Roberto Winter de Carvalho (2010, p. 32).
} 
p. 501). Ou seja, o texto da Constituição dispõe a imprescritibilidade em numerus clausus, ${ }^{6}$ não sendo uma noção decorrente de eventual omissão legal do prazo prescricional (GABARDO e SAIKALI, 2019).

Devendo ser expressa, a imprescritibilidade não pode ser extraída do art. 37, § 5ํㅡㄹ da Constituição e, desse modo, não pode ser aplicada às ações de ressarcimento. Foi esta a opção do constituinte que, quando desejou a imprescritibilidade, o fez de maneira expressa, sem deixar qualquer resquício de dúvidas. É isto o que se infere da leitura do texto constitucional, de onde são extraídas as duas condutas imprescritíveis presentes na Carta Magna: por um lado os crimes oriundos da prática de racismo e, ${ }^{7}$ por outro, as ações de grupos armados, civis ou militares, contra a ordem constitucional e o Estado Democrático. ${ }^{8}$

Não estão incluídas no rol da imprescritibilidade, portanto, as ações de ressarcimento ao erário por danos causados por atos de improbidade administrativa, sejam culposos ou dolosos. Por mais duvidosa que seja a redação do dispositivo, não se pode admitir tal regime, sob pena de ser vilipendiada a regra geral do ordenamento - a prescritibilidade, que busca a realização do princípio da segurança jurídica e a estabilidade das relações sociais.

Além do fato de a imprescritibilidade, exceção à regra, dever vir sempre expressa, não é possível entender por sua existência no parágrafo $5^{\circ}$ do art. 37 porque este dispositivo trata de uma ação patrimonial. E estas ações, tais quais as de natureza indenizatória, não podem ser consideradas como imprescritíveis, uma vez que se exercem mediante pretensões condenatórias. ${ }^{9}$ Entender pela imprescritibilidade seria consagrar ofensa ao princípio da segurança jurídica e da garantia da ampla defesa (HUMBERT, 2010, p. 184), bem como permitiria que o ente legitimado detivesse o "direito eterno" de ajuizar, a qualquer momento e ao seu bel prazer, demandas judiciais para obter a reparação de danos (PAZZAGLINI FILHO, 2018, p. 253).

A esse respeito, é preciso ter em mente o atual panorama jurídico-social brasileiro, no qual é possível observar consequências oriundas de conflitos políticos e ideológicos. Um exemplo de "direito eterno" - conforme as palavras de Marino Pazzaglini Filho - exercido a qualquer momento seria o ajuizamento de ações de ressarcimento temerárias pelo Ministério Público, com o propósito eminentemente político de minar determinado agente público. ${ }^{10} \mathrm{E}$ não se cogite apenas do MP, mas até mesmo os entes federativos (supostamente) lesados propondo demandas contra ex-agentes políticos para promover os atuais. Tais condutas estatais são igualmente maléficas e, entusiasmadas pelo apelo social, deslocam-se da ordem jurídica (FORTINI, 2018). Por razões como essas, Ada Pellegrini Grinover (2007, p. 69) afirma que o reconhecimento da prescrição perpassa, também, por

$6 \quad$ Neste sentido é a posição de Marino Pazzaglini Filho (2018, p. 253).

Art. 5ำ (...) XLII - a prática do racismo constitui crime inafiançável e imprescritível, sujeito à pena de reclusão, nos termos da lei;

$8 \quad$ Art. 5ำ (...) XLIV - constitui crime inafiançável e imprescritível a ação de grupos armados, civis ou militares, contra a ordem constitucional e o Estado Democrático;

9 "(...) Os princípios da segurança jurídica e da proibição de excesso indicam a necessidade de haver prazo de extinção da pretensão do Estado para o ressarcimento do erário pelos danos causados por ato de improbidade administrativa, porquanto se trata de pretensão civil [não penal] que se exerce mediante ação condenatória, a qual, por sua natureza, de acordo com o sistema do Direito, é sempre prescritível." (NERY JUNIOR e NERY, 2016, e-book)

10 A respeito da atuação temerária do Ministério Público, denunciando a ausência de controle sobre o ativismo ou passivismo que marcam sua atuação, ver a análise de Álvaro Ricardo de Souza Cruz e Gustavo Hermont Corrêa (2017). 
um fundamento ético; ética esta que é necessária para reforçar as condições de credibilidade na própria Administração e em seus agentes. ${ }^{11}$

Também há quem defenda que é possível que se atinja a conclusão de que inexiste previsão de imprescritibilidade no art. 37 , § 5, da Constituição, a partir da realização de uma ponderação entre princípios. É o que propõe Calil Simão (2017, p. 865-866), contrapondo o princípio da indisponibilidade do patrimônio público - representado pela imprescritibilidade - e o princípio da segurança jurídica - representado pela prescritibilidade -, ambos pautados no interesse social. De acordo com o autor, para resolver este conflito, caberia ao intérprete orientar-se pelo princípio da razoabilidade, que conduziria à conclusão de que, com a imprescritibilidade, estaríamos diante de uma "insegurança jurídica eterna, que passaria da pessoa de quem eventualmente praticou o ato danoso, estendendo-se aos seus descendentes de forma infinita". ${ }^{12}$ Assim, afirma o autor ser possível sustentar a existência de fundamento para a imprescritibilidade no texto constitucional (princípio da indisponibilidade), mas este não prevalecerá. Isto porque, a partir de uma leitura sob a óptica do princípio da razoabilidade, prepondera no ordenamento a prescritibilidade, que é uma das formas de realização do princípio da segurança.

Em sentido contrário ao de Calil Simão é o posicionamento de José dos Santos Carvalho Filho (2016, p. 247), para quem a ratio do $\S 5^{\circ}$ foi a proteção do patrimônio público. Para o autor, por maior que seja a desídia do titular da pretensão em demandar o causador do dano, a sua inércia sempre será superada e cederá em face da proteção do patrimônio público, que seria um valor maior. Este raciocínio jurídico, todavia, peca por não se atentar a uma falácia pragmática: o fato de ter a eternidade para ingressar com ações de ressarcimento não facilita a cobrança, mas sim a posterga para o infinito. Sem prazo para ingressar com a ação, as autoridades responsáveis muitas vezes deixam para depois, prolongando indefinidamente a ação até o seu esquecimento. Em tendo prazo para o ingresso, a tendência é que dele se utilizem, sob pena de serem responsabilizados. Nestes termos, o prazo prescricional é um elemento favorável ao interesse público do ressarcimento, sendo benfazejo ao erário, e não o contrário.

Com relação à divergência de posicionamentos dos autores acima, propõe-se o seguinte questionamento: seria válido, neste caso, sustentar a preservação do patrimônio público quando, a partir disso, se tem como consequência o sacrifício da segurança jurídica? Defende-se que não. Isto porque entender pela imprescritibilidade da pretensão ressarcitória da Administração acabaria por concedê-la uma prerrogativa absoluta no tempo. Esta prerrogativa eterna teria o condão de desestabilizar, a qualquer momento, as relações jurídicas consolidadas pelo passar do tempo, contrariando a segurança proposta pelo ordenamento quanto a restrição, exclusão e exercício dos direitos e deveres destinados aos seus respectivos titulares. Ademais, o fato de ser estabelecido um prazo não elimina o direito de ressarcimento, apenas o regulamenta, o que é uma resposta jurídica razoável dada pelo sistema.

11 Sobre a ligação entre ética e credibilidade, ver a doutrina de Jaime Rodríguez-Arana Muñoz (2014, p. 77).

12 A respeito disso, pertinente pontuar que esta questão está presente desde a promulgação da Constituição de 1988, como pontuou Wolgran Junqueira Ferreira ao responder ao questionamento consistente em saber se os herdeiros do agente que cometeu o ilícito responderiam pelos prejuízos causados pelo falecido: "sim, na força de sua herança, pois esta é, em tese, fruto daquele ilícito" (FERREIRA, 1989, p. 479). 
Ainda em relação a uma discussão principiológica, são trazidos a lume os princípios da isonomia e da proibição do excesso. Admitir que a Administração Pública detenha prerrogativa eterna, para além de se tratar de situação não prevista no ordenamento, configura violação ao princípio da isonomia, uma vez que não há fundamento constitucional para estabelecer distinção tão gravosa entre Estado e particular (GODOY e JUSTEN FILHO, 2018). Assim, tendo em vista que a pretensão do particular em face do Estado, por mais reprovável que seja a conduta da Administração, está sujeita à incidência de prazo prescricional, o exercício das pretensões estatais, por critérios de igualdade e de razoabilidade, deve sujeitar-se, também, a prazos extintivos.

Como exposto, a imprescritibilidade não é a regra do sistema jurídico pátrio. Pelo contrário, é a prescritibilidade, que se estende, inclusive, aos delitos que tocam os bens jurídicos mais caros do ordenamento. Isto é, prescrevem mesmo as condutas descritas como criminosas pelo Direito Penal (tido como a ultima ratio). Ainda que haja longos prazos prescricionais, as pretensões punitivas na persecução penal podem ser alcançadas pela prescrição, de modo que não ficam eternamente à disposição da autoridade competente por seu exercício.

Um exemplo recorrente da doutrina ao tratar deste paralelo com o Direito Penal é o crime de homicídio. ${ }^{13}$ Mas, ainda que não se deseje estabelecer uma correlação com o crime de homicídio, eis que distante da realidade das condutas configuradoras de improbidade administrativa que se busca reprimir, o Direito Penal também tutela comportamentos que muito se assemelham às condutas reprovadas pela Lei de Improbidade Administrativa: os crimes praticados contra a Administração Pública, seja por funcionário público, seja por particular, disciplinados pelo Título XI, do Código Penal.

Uma única conduta é capaz de ensejar a reprovação tanto na esfera civil quanto na esfera penal. Assim, não se afigura como razoável entender pela imprescritibilidade das ações de ressarcimento ao erário pelos danos causados por ato de improbidade administrativa, uma vez que é contrastante com a prescritibilidade de demandas voltadas à tutela de bens jurídicos pela esfera penal (MENDES e BRANCO, 2019, p. 961). Com a admissão da tese da imprescritibilidade, é possível verificar que a corrupção (tutelada pelo Direito penal) seja atingida pela prescrição, mas não a pretensão indenizatória por atos de improbidade administrativa. Foi isto o que tentou defender o Ministro Alexandre de Moraes ao longo do julgamento: evitar que se confira uma imprescritibilidade (implícita) a uma das consequências previstas para os atos de improbidade em sede de responsabilidade civil, imprescritibilidade esta que inexistiria na esfera penal, à qual incumbem os casos de maior gravidade,$^{14}$ supostamente.

Fato é que a interpretação do dispositivo pela imprescritibilidade, além de não coadunar com o ordenamento posto, não reflete, justamente, a opção feita pelo constituinte. É isto o que se pode concluir ao analisar os documentos históricos da Assembleia de 1987-1988, onde se optou, claramente, pela prescritibilidade das ações de ressarcimento ao erário por danos causados por atos de improbidade.

13 Esta é a posição de Fábio Medina Osório (2015, p. 457). No mesmo sentido, defende Rita Tourinho (2009, p. 282).

14 Restou consignado no Acórdão: "Não bastasse isso, não seria razoável que, considerando-se as mesmas condutas geradoras tanto de responsabilidade civil como de responsabilidade penal, houvesse imprescritibilidade implícita de uma única sanção pela prática de um ilícito civil definido como ato de improbidade, e não houvesse na esfera penal, que é de maior gravidade." (STF, 2018) 
De início, os textos embrionários da Constituição, ainda nas comissões temáticas (da Ordem Social e da Organização Eleitoral, Partidária e Garantia das Instituições; e também da Subcomissão dos Direitos dos Trabalhadores e Servidores Públicos), nominavam a disciplina como "atos de corrupção administrativa". A expressão foi mantida e integrada ao texto da Comissão de Sistematização, que dispunha que os atos de corrupção administrativa importariam "a suspensão dos direitos políticos de cinco a dez anos, a perda da função pública, a indisponibilidade dos bens e o ressarcimento ao erário, sem prejuízo da ação penal correspondente", e que seriam "imprescritíveis os ilícitos praticados por qualquer agente, servidor público ou não, que causem prejuízo ao erário, bem como as respectivas ações de ressarcimento." (Redação do Anteprojeto - Art. 80, caput e $\S 2^{\circ}-$ e do Projeto - art. 81, caput e $\S 2^{\circ}$ - de Constituição da Comissão de Sistematização).

Com uma redação quase idêntica à do texto constitucional atual, a primeira vez que o dispositivo apareceu foi no Segundo Substitutivo ao Projeto, ainda na Comissão de Sistematização, que deixou de utilizar o termo "corrupção", dando lugar à palavra "improbidade". Neste documento, restou a previsão de que "A lei estabelecerá os prazos de prescrição para ilícitos praticados por qualquer agente, servidor ou não, que causem prejuízos ao erário, ressalvadas as respectivas ações de ressarcimento, que serão imprescritíveis." (Segundo substitutivo do relator ao Projeto; art. 43, § 40; Fase P). Vê-se, claramente, que a opção do constituinte, neste momento, era consagrar a imprescritibilidade. Deixou-se esta vontade ainda mais clara do que já exprimiam os fragmentos iniciais desta etapa da elaboração do texto da Carta Magna.

Passando da fase da Comissão de Sistematização para a análise em plenário, o texto manteve esta redação no Projeto A, que teve suas discussões iniciadas em 24.11.1987. Contudo, quando da oportunidade de apresentação de emendas em plenário, um grupo de constituintes conhecido como "Centrão" apresentou uma série de proposições que vieram a ser aprovadas. Dentre as proposições, estava a Emenda Substitutiva 2P02039-9, cujo objeto no texto constitucional era a disciplina "Da Organização do Estado". Com a emenda, pretendia-se a supressão do trecho "que serão imprescritíveis" e, consequentemente, da previsão de imprescritibilidade que até então fora a opção dos constituintes. ${ }^{15}$

A referida emenda foi aprovada em $11.03 .1988,{ }^{16}$ extirpando do texto constitucional a previsão da imprescritibilidade para as ações de ressarcimento relativas a dano causado por ato de improbidade. E essa opção final do constituinte fica bastante clara quando realizado um cotejo entre as redações que se tentou dar ao dispositivo ao longo do processo constituinte:

15 A breve - e única - justificativa dada a esta emenda foi: "as alterações introduzidas neste Título visam, em especial, retirar do texto do Projeto preceitos que o tornavam extremamente estatizante, haja vista alguns dos incisos do artigo 22, em virtude dos quais a União passaria a ter o domínio das riquezas do subsolo e dos recursos minerais de maneira geral. Isto significaria a estatização de um setor econômico que, em nosso País, nunca pertenceu ao Estado, ao contrário do que alguns podem pensar, com graves repercussões na atividade econômica. De outra parte, no que diz respeito às competências legislativas e administrativas dos entes federados buscou-se, igualmente, escoimar o texto de alguns excessos e impropriedade que, da mesma forma, tendiam a permitir um maior avanço do Estado no meio econômico, sem prejuízo da melhoria da redação que se impunha para adequação mais precisa do texto às finalidades que se propõe."

${ }_{16}$ Diário 203, de 11/03/1988, da Assembleia Nacional Constituinte. Disponível em: http://imagem.camara.gov.br/lmagem/d/pdf/203anc11mar1988.pdf\#page= Acesso em: 12 fev. 2020. Na mesma sessão que aprovou a Emenda 2P02039-9, foi votada outra emenda, que desejava disciplinar os atos de improbidade de administrativa como crimes inafiançáveis. Esta emenda foi rejeitada pela maioria dos constituintes. 


\begin{tabular}{|c|c|c|}
\hline $\begin{array}{l}\text { Projeto de Constituição } \\
\text { (Fase } L)\end{array}$ & $\begin{array}{l}\text { Segundo Substitutivo do } \\
\text { Relator (Fase P) }\end{array}$ & Emenda 2P02039-9 (Fase S) \\
\hline $\begin{array}{l}\text { Art. } 81 \text { (...) } \S 2^{0}-\text { São } \\
\text { imprescritíveis os ilícitos } \\
\text { praticados por qualquer } \\
\text { agente, servidor público ou } \\
\text { não, que causem prejuízo ao } \\
\text { erário, bem como as } \\
\text { respectivas ações de } \\
\text { ressarcimento. }\end{array}$ & $\begin{array}{l}\S 4^{\circ} \text { - A lei estabelecerá os } \\
\text { prazos de prescrição para } \\
\text { ilícitos praticados por } \\
\text { qualquer agente, servidor ou } \\
\text { não, que causem prejuízos } \\
\text { ao erário, ressalvadas as } \\
\text { respectivas ações de } \\
\text { ressarcimento, que serão } \\
\text { imprescritíveis. }\end{array}$ & $\begin{array}{l}\text { Art. } 38 \text { (...) } \S 5^{\circ} \text { A lei } \\
\text { estabelecerá os prazos de } \\
\text { prescrição para ilícitos } \\
\text { praticados por qualquer } \\
\text { agente, servidor ou não, que } \\
\text { causem prejuízos ao erário, } \\
\text { ressalvadas as respectivas } \\
\text { ações de ressarcimento. }\end{array}$ \\
\hline $\operatorname{Imp}$ & & \\
\hline
\end{tabular}

Inicialmente, desejou-se o regime da imprescritibilidade. Esta aspiração - que era evidente no texto constitucional - ia ainda mais longe, uma vez que se estendia a todas as sanções aplicáveis aos casos de improbidade. Com as mudanças do texto, continuava expressa a intenção do constituinte em estabelecer a imprescritibilidade das ações de ressarcimento. Contudo, não foi este o resultado final do dispositivo, uma vez que foi eliminada a previsão da imprescritibilidade.

O texto constitucional dispunha, de forma clara e inequívoca, que as ações de ressarcimento não estariam submetidas a qualquer regime prescricional. Assim, estaria de acordo com a lógica do texto que, quando desejou o regime atípico da imprescritibilidade, o fez de maneira expressa e inequívoca. Contudo, o constituinte, não desejando outra hipótese de imprescritibilidade para o texto constitucional, suprimiu do dispositivo os termos "que serão imprescritíveis". Do contrário, não haveria razão outra para excluir este fragmento do texto, se não para sepultar a ideia de que as ações de ressarcimento seriam imprescritíveis.

Ainda que brevemente, o Min. Alexandre de Moraes suscitou o afastamento da imprescritibilidade a partir de uma interpretação histórica do dispositivo. Na ocasião, relembrou o argumento utilizado pelo Min. Luís Roberto Barroso quando do julgamento do RE 669.069, ${ }^{17}$ em que também se discutiu acerca da prescritibilidade das ações de ressarcimento, contudo, decorrentes de atos ilícitos civis. De acordo com o Ministro Relator, o constituinte, ao expurgar do texto constitucional a expressão "que serão imprescritíveis" - clara e incisiva no estabelecimento da imprescritibilidade -, optou por privilegiar a segurança jurídica. ${ }^{18}$

17 O Recurso Extraordinário 669.069/MG foi o leading case do Tema 666 da Repercussão Geral do STF: Imprescritibilidade das ações de ressarcimento por danos causados ao erário, ainda que o prejuízo não decorra de ato de improbidade administrativa. Com seu julgamento, fixou-se a seguinte tese: "É prescritível a ação de reparação de danos à Fazenda Pública decorrente de ilícito civil."

18 Assim afirmou o Ministro Alexandre de Moraes, em seu voto: "Antes de ser uma decisão isolada da Assembleia Nacional Constituinte, a exclusão dessa hipótese de imprescritibilidade foi uma clara e consciente opção em privilegiar a segurança jurídica, restringindo ao máximo essas excepcionalidades que causavam grande desconforto nos debates entre os constituintes." 
Desta maneira, é equivocada a afirmação de que a exclusão da expressão do texto constitucional consistiria em simples aprimoramento de estilo. ${ }^{19}$ Não há aprimoramento estético que justifique tornar o texto constitucional obscuro. Embora o texto do dispositivo resultante da Constituinte prescinda de boa redação, a sua interpretação histórica demonstra que não alberga a imprescritibilidade. Não há omissão, mas sim um silêncio eloquente (GABARDO e SAIKALI, 2018, p. 60). O que desejou o constituinte, em bem da verdade, foi a submissão das ações de ressarcimento ao regime da prescritibilidade, regime este que não coincidiria com as regras prescricionais aplicáveis às sanções a serem regulamentadas pela Lei de Improbidade Administrativa.

A primeira parte do dispositivo ("a lei estabelecerá os prazos de prescrição para ilícitos praticados por qualquer agente, servidor ou não, que causem prejuízos ao erário") teve seu comando atendido pelo legislador infraconstitucional, porquanto a Lei de Improbidade Administrativa (Lei $n$. 8.429/92) fixou os prazos para a prescrição das sanções aplicáveis às condutas ímprobas elencadas pela lei. ${ }^{20}$

A respeito, importante ter em mente que o constituinte não desejou que as ações de ressarcimento fossem regulamentadas pela LIA, "até porque o ressarcimento ao erário não se esgota na conduta ímproba, haja vista que pode haver lesão ao patrimônio público por ato não considerado ímprobo" (SIMÃO, 2017, p. 867). Desejou-se, portanto, a distinção entre as pretensões sancionatória e ressarcitória, ${ }^{21}$ para que não ficassem vinculadas a uma mesma legislação. Esta questão resta bem explicada na doutrina de Celso Antônio Bandeira de Mello (2019), que afirma ser intenção da norma constitucional a de separar os prazos de prescrição do ato ilícito dos prazos prescricionais das ações de responsabilidade, uma vez que não teriam que, necessariamente, coincidir. Assim, a ressalva contida no texto constitucional implica que as ações de ressarcimento terão prazos autônomos em relação aos que a lei fixar para a responsabilidade dos atos ilícitos. ${ }^{22}$

A segunda parte do dispositivo, núcleo das controvérsias, que dispõe a ressalva acerca das ações de ressarcimento, também foi respeitada pelo legislador infraconstitucional, uma vez que não foi fixado qualquer prazo prescricional às ações de ressarcimento. $E$ isto não porque elas são imprescritíveis, mas porque o constituinte não queria submetê-las ao mesmo regime de prescrição dos ilícitos praticados pelos agentes.

Desta forma, como já se tem mencionado desde o início do presente artigo, as ações de ressarcimento de danos causados ao erário por ato de improbidade administrativa estão sujeitas, sim, a prazos prescricionais. E, em observância à ideia de simetria processual, ao princípio da razoabilidade, e à coerência do ordenamento jurídico pátrio, este prazo deve ser de cinco anos, tal qual previsto no Decreto Federal $20.910 / 32,{ }^{23}$ que o fixa como limite ao exercício de todos os direitos

19 "A exclusão da referência expressa à imprescritibilidade pode e deve ser encarada como simples aprimoramento do estilo do texto, para que dele fosse expurgada uma evidente redundância. A imprescritibilidade já estava consagrada na ressalva, sendo abundante a referência expressa a ela. Daí por amor ao melhor estilo, a extirpação dessa referência." (DECOMAIN, 2014, p. 477)

$20 \quad$ Neste sentido é a doutrina de Marçal Justen Filho (2018, p. 1.350), Arnaldo Rizzardo (2014, p. 586) e Calil Simão (2017, p. 867).

$21 \quad$ Também aderiram a esta posição Carlos Ari Sundfeld e Rodrigo Pagani de Sousa (2017).

22 No mesmo sentido asseveram Marino Pazzaglini Filho (2018, p. 253) e Emerson Gabardo (2009, p.

313).

23 Decreto 20.910/1932 - Art. 1ํ As dívidas passivas da União, dos Estados e dos Municípios, bem assim todo e qualquer direito ou ação contra a Fazenda federal, estadual ou municipal, seja qual for a sua natureza, 
ou ações contra a Fazenda Pública, e na Lei $9.494,{ }^{24}$ que o utiliza como limite ao exercício de pretensões indenizatórias por danos causados por agentes públicos.

E não há que se falar que tal prazo dificultaria o exercício da pretensão pela Administração. A Constituição impôs que, aos atos de improbidade administrativa importarão a suspensão dos direitos políticos, a perda da função pública, a indisponibilidade dos bens e o ressarcimento ao erário, na forma e na gradação previstas pela lei (LIA). Por mais que não se conceba o ressarcimento como uma sanção, ${ }^{25}$ o constituinte fez questão de elencá-lo dentre as consequências que recairão sobre aquele que for ímprobo no trato da coisa pública. E, por assim ser, o momento de apuração da conduta coincidiria com o momento de apuração do suposto dano ao erário, ainda que o agente público esteja ocupando o cargo no momento da investigação, "pois o termo a quo é tão somente da contagem do prazo prescricional, o que não significa que o agente político não possa ser investigado". (CRUZ, 2014, p. 409).

Entender de maneira contrária, pela imprescritibilidade, seria consagrar a "minimização ou a supressão do direito de defesa subjetivado pelo autor do dano ao erário" (BANDEIRA DE MELLO, 2019, p. 1.124). Isto porque não é razoável que se acomode documentação de caráter probatório por tempo excessivamente longo (desarrazoado). Vale dizer, o particular só guarda elementos de prova por um período determinado. Após, acaba por deles se desfazer. Não é o que sucede com os órgãos públicos, que tem estrutura e podem fazê-lo eternamente. Em consequência, o suposto responsável pelo prejuízo ficaria indefeso diante da pretensão perene do Estado em demandá-lo, o que ocorreria apenas no momento em que este decidisse promover a ação ressarcitória - possibilitando, inclusive, o uso de má-fé deste "poder de agenda".

O tempo passa, fazendo com que as relações se estabilizem e novas expectativas sejam criadas, os documentos e as provas se percam, as testemunhas se esqueçam ou até mesmo venham a falecer. Por estas razões e sob o manto do Estado Democrático de Direito, que consagra a ampla defesa como direito do demandado, não há como se aceitar a imprescritibilidade (MARINONI e MITIDIERO, 2015, p. 764).

Entender pela imprescritibilidade faria com que, na prática, este regime se configurasse como verdadeira sanção, uma vez que dispõe de caráter notadamente aflitivo sobre o administrado que fica à mercê do Estado detentor da eterna pretensão ressarcitória. Pior ainda, seria uma sanção de caráter perpétuo, ${ }^{26}$ o que é vedado pelo ordenamento jurídico (art. $5^{\circ}, \mathrm{XLVII}$, 'b'), pois, caso não

prescrevem em cinco anos contados da data do ato ou fato do qual se originarem. No mesmo sentido, adotando especificamente o prazo de cinco anos previsto no decreto, posicionam-se Marcelo Colombelli Mezzomo (2002), bem como Romeu Felipe Bacellar Filho e Daniel Wunder Hachem (2010, p. 52). Aderiram também à posição Miguel Gualano de Godoy e Marçal Justen Filho (2018).

$24 \quad$ Lei 9.494/97 - Art. 1ํ-C Prescreverá em cinco anos o direito de obter indenização dos danos causados por agentes de pessoas jurídicas de direito público e de pessoas jurídicas de direito privado prestadoras de serviços públicos.

25 "O STJ tem assentado o entendimento de que o ressarcimento não constitui sanção propriamente dita, mas sim consequência incontornável do prejuízo causado. Caracterizada a improbidade administrativa por dano ao Erário, a devolução dos valores é imperiosa e deve vir acompanhada de pelo menos uma das sanções legais previstas no art. 12 da Lei n. 8.429/1992". Neste sentido: REsp 1761202/MG, Rel. Ministro Herman Benjamin, Segunda Turma, julgado em 27/11/2018; Aglnt no REsp 1.570.402/SE, Rel. Ministro Benedito Gonçalves, Primeira Turma, julgado em 03/04/2018.

26 Esta é a posição de Antonio Roberto Winter de Carvalho (2010), que é acompanhada por Erico Andrade (2003, p. 49). 
exercida a pretensão, o indivíduo será penitenciado até sua morte, assim como seus herdeiros continuarão a ser potencialmente afligidos (BANDEIRA DE MELLO, 2019, p. 1.124). ${ }^{27}$

A ausência de delimitação temporal para o exercício da ação acaba por gerar uma "intolerável insegurança jurídica" (OSÓRIO, 2015). Na busca pela recomposição do erário, o indivíduo é submetido ao regime da imprescritibilidade, por mais que a aplicação das sanções previstas na Lei de Improbidade Administrativa já esteja prescrita. Assim, mesmo que não se conceba a imprescritibilidade como sanção, a realidade fática acaba por configurá-la como tal.

Segundo a decisão do STF no RE 852.475/SP ao indivíduo que tenha cometido danos ao erário a partir de atos de improbidade (qualificada pelo dolo), a sanção que the será aplicada é a imprescritibilidade, retirando a segurança de suas relações jurídicas, de modo que pode vir a ser acionado a qualquer momento pelo legitimado que busca o ressarcimento. Ao arrepio ao arrepio do ordenamento, decidiu-se por cindir a incidência da imprescritibilidade alocando-a apenas aos atos de improbidade dolosos e liberando tal ônus no caso dos culposos.

A tese fixada foi a de que "são imprescritíveis as ações de ressarcimento ao erário fundadas na prática de ato doloso tipificado na Lei de Improbidade Administrativa". Ao decidir desta maneira, o STF acaba por desvirtuar o instituto da prescrição, uma vez que restará condicionado à demonstração de elemento subjetivo, vinculado a atributos pessoais. Retira-se da prescrição o seu caráter de realizador da segurança jurídica. Originalmente, em virtude da garantia da estabilidade das relações jurídicas, a prescrição justamente impediria a discussão de determinados assuntos no processo. Ao contrário, segundo a decisão do STF, a sua aplicação passou a ser uma consequência da demonstração da ausência de dolo no caso discutido - invertendo a pauta. Noutras palavras, a prescrição acaba por se tornar uma decorrência do mérito, razão pela qual o que se verifica é a desnaturação do instituto.

\section{O INCONSTITUCIONAL CONDICIONAMENTO DA PRESCRIÇÃO À ANÁLISE DO MÉRITO DA CAUSA}

Ao defenderem seus entendimentos acerca da interpretação do art. $37, \S 5^{\circ}$, diversos autores, sejam aqueles que sustentam a prescritibilidade, ${ }^{28}$ sejam aqueles que sustentam a imprescritibilidade, ${ }^{29}$ socorrem-se com a noção enunciada por Antônio Câmara Leal, para quem a prescrição "é a extinção de uma ação ajuizável, em virtude da inércia de seu titular durante um certo lapso de tempo, na ausência de causas preclusivas de seu curso" (CÂMARA LEAL, 1978, p. 12).

Ou seja, para que se configure a prescrição, é necessário que se esteja diante de um panorama no qual o titular de uma pretensão tenha deixado seu prazo prescricional transcorrer sem que tenha ocorrido qualquer causa impeditiva, suspensiva ou interruptiva do transcurso do lapso temporal. Assim, a partir da concepção clássica proposta por Câmara Leal, Marino Pazzaglini Filho (2018, p. 251), elencou os requisitos aos quais a prescrição está subordinada: (i) existência de ação

$27 \quad$ Em sentido contrário, entendendo que não há nada de errado em demandar de herdeiros, mesmo após duas ou até três décadas, desde que realizada uma ponderação de princípios à luz do caso concreto, Ricardo Marcondes Martins (2010).

$28 \quad$ Como é o caso de Ada Pellegrini Grinover (2007).

29 Como é o caso de Marcelo Figueiredo (2009). 
exercitável; (ii) inércia do titular da ação pelo seu não exercício; (iii) continuidade dessa inércia durante certo lapso de tempo; e (iv) ausência de fato ou ato, por lei, impeditivo, suspensivo ou interruptivo do curso prescricional. Assim, quando concomitantemente verificados todos os requisitos, estar-se-á diante de uma situação em que se tem operada a prescrição, restando fulminada, portanto, a pretensão ressarcitória do titular.

Dos fatores acima listados, não se vislumbra qualquer atributo subjetivo apto a obstar a incidência da prescrição no caso concreto. E sempre foi assim: desde os civilistas mais antigos (ainda que menos abrangentes que Câmara Leal na definição da prescrição), não se utiliza qualquer elemento subjetivo para a operação da prescrição. É o caso de Clóvis Beviláqua (1955, p. 271), para quem os requisitos da prescrição reduzem-se (i) à negligência ou inação do titular do direito e (ii) ao decurso do tempo. E não poderia ser diferente, uma vez que, para a verificação da prescrição no caso concreto, não se afigura exigível "nenhuma condição particular do agente ou qualquer outra circunstância” (CRETELLA JÚNIOR, 1991, p. 2260).

Configurando-se como "indispensável à estabilidade e consolidação de todos os direitos" (GONÇALVES, 1955, p. 633), a incidência da prescrição - assim como outros fenômenos extintivos de direitos -, através do impedimento da discussão de determinadas matérias ou do exercício de certo direito, não possui como objetivo precípuo a condenação da inércia do titular, mas, antes de tudo, assegurar para as relações jurídicas a obtenção do atributo da certeza, ${ }^{30}$ bem como garantir a estabilidade.

Ou seja, a prescrição que, "em princípio, atinge a todas as pretensões e ações, quer trate de direitos pessoais, que de direitos reais, privados ou públicos" (PONTES DE MIRANDA, 1974, p. 127), é instrumento pelo qual se busca a realização do princípio da segurança jurídica não somente como uma garantia individual, mas, também, como inegável prerrogativa de ordem pública em defesa da coletividade.

Para que haja discussão acerca do ressarcimento ao erário em virtude de ato de improbidade, é preciso, primeiramente, que se constate a existência do referido ato. E a Lei de Improbidade Administrativa determinou que a ação voltada à apuração do (suposto) ato ímprobo seria regida pelo rito ordinário, mas, com as peculiaridades dispostas no art. 17, da Lei (HARGER, 2015. p. 175). Ou seja, a ação de improbidade administrativa segue, na verdade, um rito específico.

Uma das peculiaridades do rito específico da ação de improbidade consiste na etapa de apresentação da defesa prévia pelo réu, após a qual o juiz realizará um exame de admissibilidade prévio, decidindo se receberá ou não a petição inicial formulada por qualquer dos legitimados. Esta etapa serve de barreira ao ajuizamento de ações de improbidade tidas como temerárias, onde o juiz analisará se a ação proposta dispõe de indícios mínimos ao seu processamento. Isto porque apenas o processamento desta ação já é suficiente para ser causar uma oneração subjetiva ao demandado (GABARDO e SAIKALI, 2018, p. 63). Nesta etapa, frise-se, já seria possível arguir a prescrição, demonstrando que a pretensão ressarcitória estaria fulminada, impondo-se, consequentemente, a extinção do feito.

30 Sobre a questão da certeza e estabilidade, merece destaque a doutrina de José Armando da Costa (2005, p. 206), bem como a de Flávio Luiz Yarshell, Guilherme Setoguti e Viviane Siqueira Rodrigues (2016). 
Ocorre que a decisão do STF acaba por reforçar o problema histórico acerca do assunto, qual seja, o rito a ser empregado na ação de ressarcimento. Não bastando ter limitado a incidência da prescrição apenas aos atos culposos, restou afirmado que a ação de ressarcimento seguiria o rito de ação ordinária, ${ }^{31}$ sem qualquer consideração ao rito específico da ação de improbidade. Aliás, até mesmo antes da decisão da Suprema Corte já havia entendimento do Superior Tribunal de Justiça pela não aplicação do rito especial da Lei de Improbidade Administrativa ao ressarcimento (o que, obviamente, é um absurdo). ${ }^{32}$

Assim, impondo-se a discussão do ato de improbidade - não é possível discutir o ressarcimento em razão da improbidade sem que se constate a existência do próprio ato - no procedimento comum, o acusado "perderia" esta etapa de juízo de admissibilidade da ação. Por esta razão, é equivocada a decisão do Supremo. Por certo que será inevitável o cerceamento de defesa do demandado, já que haverá discussão acerca da (in)existência de atos de improbidade fora do rito específico fixado pelo legislador, sem que sejam impressas as formalidades processuais previstas pela Lei de Improbidade em favor do réu, tal qual a fase de defesa preliminar.

Caso se tratasse exclusivamente da pretensão ressarcitória (independentemente de se estar discutindo atos de improbidade), não haveria problema, uma vez que a prescrição poderia ser arguida quando da contestação da ação de ressarcimento. E, ainda que não alegada, ou alegada de maneira processualmente inadequada, ${ }^{33}$ o juiz deve reconhecê-la ${ }^{34}$ porquanto a prescrição é uma matéria de ordem pública, cognoscível de ofício pelo magistrado. ${ }^{35}$

Mas, após a decisão do STF, não é isso o que ocorrerá nas ações oriundas de ato de improbidade, uma vez que o juiz postergará a análise da alegação de prescrição - formulada pelo réu - para um momento processual posterior. Especificamente, aguardará o desdobramento do mérito do

$31 \quad$ Trecho do voto do Ministro Luís Roberto Barroso: "Eu estou Presidente, reajustando o meu voto para considerar a imprescritibilidade nas hipóteses de improbidade dolosa. Aqui eu acho que não é o caso de se discutir rito, mas eu, pessoalmente, nem acho que seja rito de improbidade. Penso que é uma ação provavelmente ordinária de ressarcimento, que tem como questão prejudicial o prévio assentamento de que ocorreu um ato de improbidade com todo o direito de defesa do réu também nesta hipótese e sem que nesta ação, como me parece intuitivo, se possa pretender aplicar qualquer sanção associada à improbidade, porque o ressarcimento ao erário não é uma sanção." (STF, 2018).

$32 \quad$ Trata-se do posicionamento adotado pelo Superior Tribunal de Justiça quando do julgamento do Tema 344, dos Recursos Repetitivos. Diferenciando a ação de ressarcimento da ação de improbidade, afirmou-se que essa dispõe de caráter repressivo, voltada à aplicação de sanções político-civis de natureza pessoal aos responsáveis por atos de improbidade administrativa (art. 12), ao passo que as ações de ressarcimento, tem por objeto consequências de natureza civil comum, suscetíveis de obtenção por outros meios processuais. Assim, foi adotada a seguinte tese: "O especialíssimo procedimento estabelecido na Lei 8.429/92, que prevê um juízo de delibação para recebimento da petição inicial (art. 17, §§ 8ำ e 9), precedido de notificação do demandado (art. $\left.17, \S 7^{\circ}\right)$, somente é aplicável para ações de improbidade administrativa típicas."

33 Deve-se ter em mente, ainda, que, por força do Artigo 193, do Código Civil, "a prescrição pode ser alegada em qualquer grau de jurisdição, pela parte a quem aproveita”, até mesmo em que fase de recursos perante as Cortes Superiores, desde que devidamente prequestionada (REsp 1805418/RJ, Rel. Ministro Herman Benjamin, Segunda Turma, julgado em 27/08/2019), ou que não tenha operado a preclusão consumativa (AgRg no AREsp 264.238/RJ, Rel. Ministro Antonio Carlos Ferreria, Quarta Turma, julgado em 15/12/2015). Portanto, a partir da combinação do art. 193, do CC, com o art. 342, II e III, do Código de Processo Civil, o demandado pode alegar a prescrição a qualquer momento.

$34 \quad$ A necessidade de reconhecimento é bem explicada por Fábio Ulhoa Coelho (2016).

35 É este o entendimento pacífico do Superior Tribunal de Justiça. A exemplo: REsp 1.834.003/SP, Rel. Ministro Ricardo Villas Bôas Cueva, Terceira Turma, julgado em 17/09/2019, DJe 20/09/2019; EDcl no REsp 1.682.995/ES, Rel. Ministro Herman Benjamin, Segunda Turma, julgado em 07/12/2017, DJe 19/12/2017; Aglnt nos EDcl no REsp 1250171/SP, Rel. Ministra Maria Isabel Gallotti, Quarta Turma, julgado em 27/04/2017, DJe 05/05/2017. 
caso, para saber se incide ou não a prescrição. Passa-se a depender de uma variável futura para a consideração de um elemento precedente - um autêntico paradoxo.

Novamente, resta vilipendiado o direito de defesa do demandado. E não somente, pois a segurança jurídica do ordenamento também é desconsiderada, já que os magistrados - assim como os demandados - sequer poderão contar com a hipótese de improcedência liminar do pedido tão logo reste verificada a prescrição, que ocorreria independentemente da citação do réu (THEODORO JÚNIOR, 2016, p. 775), conforme institui o art. 332, § 1ํㅡ, do Código de Processo Civil. Com isto, seriam deixados de lado os princípios da celeridade e da economia processuais, informadores da improcedência liminar do pedido e fundantes do processo civil brasileiro (WAMBIER e TALAMINI, 2016, p. 115). ${ }^{36}$

Assim, deixa-se de apreciar as alegações do réu por vários momentos processuais. De início, tem-se a supressão da fase de apresentação de defesa prévia, uma vez que se pretende que o ressarcimento siga o rito ordinário. Em segundo lugar, arguida na primeira oportunidade em que o réu comparece ao processo (a contestação), o juiz deixará de reconhecê-la, uma vez que, provavelmente, não estará confiante acerca do dolo ou da culpa do suposto ato de improbidade discutido. Assim, o juiz seguirá a marcha processual com a instrução de todo o feito, determinando a realização de atos que, em caso de reconhecimento da prescrição da pretensão, inexistiriam e não fariam com que as partes se sujeitassem ao processo por período indefinido de tempo.

Instruídas as ações de improbidade (que se prolongam por anos) como se não houvesse prescrição, o juiz analisará os fatos alegados e as provas produzidas no bojo do processo, ainda que com o direito de defesa do acusado prejudicado, pois, como já se viu acima, poderá carecer de provas documentais, testemunhais e até mesmo de sua própria memória. Será analisado todo o mérito do caso e, somente quando constatado que não se trata de ato doloso de improbidade é que o magistrado declarará prescrita a pretensão do autor. Trata-se, na verdade, de uma construção absurda feita pelo STF.

A prescrição, para as partes de uma relação processual, é, efetivamente, uma matéria a ser invocada pelo réu. ${ }^{37} \mathrm{E}$ ainda que seja uma matéria de mérito, é arguida de maneira preambular, antes que se passe à dedução das alegações propriamente meritórias. Por esta razão, é considerada uma preliminar. ${ }^{38}$ José Carlos Barbosa Moreira vai além, afirmando que é uma preliminar de mérito. ${ }^{39} \mathrm{De}$ qualquer modo, resta evidente que é oportuno que seja solucionada antes do meritum causae propriamente dito. ${ }^{40} \mathrm{Ou}$ seja, uma vez acolhido o argumento acerca da prescrição, não se avança

\footnotetext{
36 Ainda assim, não se pode falar em inobservância ao direito ao contraditório, uma vez que, julgada liminarmente improcedente à demanda em virtude da prescrição, o autor da demanda pode recorrer e viabilizar a retratação do juiz de primeiro grau. Assim, o contraditório é plenamente exercido na apelação, onde o juiz pode rever sua decisão. Neste sentido, defendem Luiz Guilherme Marinoni, Sérgio Cruz Arenhart e Daniel Mitidiero (2019, p. 180).

$37 \quad$ Conforme a clássica lição de Enrico Tullio Libman (1984, p. 170).

38 “(...) são questões internas a um processo cuja solução poderá condicionar a própria emissão do julgamento do mérito ou talvez excluí-lo, mas não influir em seu teor." (DINAMARCO e LOPES, 2018, p. 176)

39 "(...) questões que, dizendo respeito já à própria res in iudicium deducta, podem tornar supérfluo, se resolvidas de certa maneira, o exame dos restantes aspectos da lide - e, por isso mesmo, são apreciadas em primeiro lugar. É o caso da questão referente à prescrição". (BARBOSA MOREIRA, 1967, p. 31-32).

$40 \quad$ Nesse sentido é a doutrina de Georges Abboud e José Carlos Van Cleef de Almeida Santos (2016).
} 
mais sobre a questão meritória, ${ }^{41}$ o que acaba culminando na improcedência do pedido, nos termos do art. 487, II, do Código de Processo Civil (DIDIER JUNIOR, 2015, p. 442).

No raciocínio firmado pelo STF, a prescrição deixa de cumprir com seu papel primordial, qual seja o de realização da segurança jurídica, e passa a ser condicionada ao mérito, mérito este que, originalmente, teria sua discussão impedida justamente em virtude do decurso do prazo prescricional. A partir do julgamento do Supremo, em ações de ressarcimento ao erário por ato de improbidade administrativa, a prescrição passa a ser pensada como um instituto de aplicação secundária no curso do processo.

Se não uma figura condicionada pelo mérito, tem-se que a sua aplicação é uma decorrência do mérito. O processo seguirá normalmente como se a pretensão não estivesse prescrita, devendo ser suportado pelo réu (ainda que inocente, ou então que não tenha agido com dolo) até a prolação de sentença. Neste caso, somente a partir da ausência de dolo na conduta do réu - constatada a partir de uma análise aprofundada do mérito - é que poderá ser aplicada a prescrição.

Em verdade, verifica-se uma aberração jurídica. Isto porque, nos casos em debate, o STF entende que é possível que a prescrição - instrumento apto a garantir a estabilidade das relações sociais, dando cumprimento à segurança jurídica - seja aplicada somente ao final do processo, após verificação de toda e qualquer matéria de mérito alegada, em especial a subjetividade do indivíduo.

Tanto é assim que nem mesmo autores que entendem pela imprescritibilidade concordam com a decisão tomada pelo STF no RE 852.475/SP. A exemplo, a recente manifestação de Daniel Amorim Assumpção Neves e Rafael Carvalho Rezende Oliveira, para quem não se vislumbra "a adoção no texto constitucional da distinção entre atos dolosos e culposos de improbidade para fins de improbidade, tal como assentou a Suprema Corte" (2019, p. 128). ${ }^{42}$

Durante este trabalho, não foram encontradas previsões constitucionais ou legais que subsidiassem o entendimento adotado pela Corte Constitucional. Quanto à doutrina, foram encontrados apenas dois autores que retratam uma separação dos prazos prescricionais de acordo com o dolo e a culpa do agente ímprobo. O primeiro deles é Celso Antônio Bandeira de Mello, que, ao tratar do prazo prescricional aplicável aos casos de dano ao erário, propõe que sejam aqueles previstos para decretação de invalidade dos atos administrativos viciados: cinco anos quando não houver má-fé; e dez anos quando houver (2019, p. 1.124). Entretanto, não se concorda com a diferenciação proposta pelo autor, pois, como já exposto, na maioria dos casos, só será possível confirmar a conduta culposa ou dolosa na fase final do processo, muito depois de quando seria possível declarar a extinção do feito em virtude da prescrição. Isso faz com que o réu (mesmo inocente ou acobertado pela prescrição) tenha que suportar todo o processo, para, só ao final, descobrir se tem "direito" à prescrição. De todo modo, o autor extrai seu posicionamento de uma analogia legal, prestigiando a prescritibilidade e apenas diferenciando os prazos - o que seria perfeitamente admissível no sistema normativo, ainda que não seja a melhor solução. Não há

41 "Reconhecida a prescrição, fica o juiz dispensado de prosseguir na sua atividade cognitiva, mas nenhuma indicação daí se tira quanto ao modo por que ele decidiria, se tivesse de prosseguir". (BARBOSA MOREIRA, 1967, p. 26). No mesmo sentido previu o REsp 1573825, Rel Min, Luis Felipe Salomão, Quarta Turma, julgado em 31/10/2018, publicado em 06/11/2018, Decisão monocrática.

42 No mesmo sentido, pela inexistência de distinção em atos dolosos ou culposos para a incidência da prescrição, ainda que não se manifeste acerca da intenção do texto constitucional: PINHO, 2020, p. 284. 
qualquer relação entre esta posição de Bandeira de Mello e a ratio decidendi do STF, que criou uma distinção interpretando um dispositivo que claramente continha sentido diverso.

Outro autor que apresenta a tese da separação entre condutas dolosas e culposas para fins de discussão da aplicação da prescrição em ações de ressarcimento é Teori Zavascki, de acordo com quem, a partir da não realização de uma interpretação restritiva do art. 37 , § 5을 da Constituição - ou seja, aquela em conjunto com o $\S 4^{\circ}$-, seria possível atingir "resultados incompatíveis com o sistema, como considerar imprescritíveis ações de ressarcimento fundadas em danos causados por seus agentes por simples atos culposos" (2014, p. 71). Como repisado no parágrafo acima, não se concorda com a subordinação da prescrição ao elemento subjetivo do agente. Aqui, talvez, esteja a origem do problema hermenêutico - na análise nonsense de Zavascki, em certa medida recuperada implicitamente por Barroso.

Fato é que, embora sejam grandes doutrinadores e os únicos que tenham sido encontrados diferenciando os prazos prescricionais para condutas dolosas e culposas, nenhum dos autores foi mencionado pelo Ministro Luís Roberto Barroso, responsável pela sugestão de cisão. Em bem da verdade, Barroso não amparou - ou não quis amparar - sua tese em nenhum doutrinador, de modo que se entende a tese como criação própria (ainda que, como visto, isso não seja exatamente assim). Contudo, a tese é contraditória aos valores que ele mesmo sustentou durante o julgamento. ${ }^{43}$ Ademais, opõe-se às orientações de que: 1. "a construção do significado da norma constitucional não deve conduzir ao subjetivismo", ${ }^{44}$ e 2 . o juiz constitucional não deve adicionar regras à Constituição. ${ }^{45}$

Verifica-se, portanto, que, ao fixar sua tese, o Supremo desejou que as ações sejam ajuizadas e instruídas, e, somente ao final, quando constatado que o ato de improbidade não é doloso, seja reconhecida a prescrição da pretensão ressarcitória. Contudo, os operadores do Direito podem vir a se deparar com outro resultado. Isto porque a improcedência da ação de ressarcimento pode estar fundamentada não em virtude da declaração da prescrição - que ocorrerá somente após a análise do mérito e a conclusão pela improbidade culposa -, mas, sim, em decorrência da inexistência de ato de improbidade administrativa.

A fundamentar seu pedido de ressarcimento, por mais que já tenham passados vários anos do suposto evento danoso, o autor da ação deverá requerer, preambularmente, o reconhecimento da existência do ato doloso de improbidade. Ao julgar que o ato de improbidade não é doloso - seja por se tratar de ato culposo de improbidade, seja por se tratar de mero ato irregular que não configura improbidade -, já se teria, por si só, a improcedência da demanda. Em observância ao princípio da primazia do julgamento de mérito, verificado o ato culposo, o magistrado fundamentará a improcedência com base nesta constatação, que, a partir da tese fixada pelo STF, atrairá a declaração de prescrição. Até aí, por mais estranho que se possa conceber a aplicação da prescrição

$43 \quad$ “(... É que, em primeiro lugar, um juiz deve reconduzir a sua decisão a uma norma jurídica. Este é o passo inicial, portanto, o juiz não pode decidir com base na Bíblia, com base no Alcorão, com base no marxismo/leninismo ou com base em qualquer outra filosofia. Ele precisa ter uma norma jurídica a qual reconduza a sua decisão. Esta norma jurídica pode ser um princípio ou pode ser uma regra, mas, seja como for, as possibilidades e limites da atuação do juiz devem estar dentro das possibilidades semânticas da norma que Ihe cabe interpretar, fora disso, é legislação ou é invenção. Portanto, o primeiro passo que o juiz deve fazer é interpretar a norma dentro das possibilidades semânticas que ela oferece. (...)". (STF, 2018)

$44 \quad$ Proposição de Luiz Fernando Diniz Araújo (2018, p. 143).

45 Proposição de Edilson Pereira Nobre Júnior (2017, p. 156). 
- cujo objetivo é obstar, de plano, a pretensão do autor - apenas ao final do processo, os julgamentos proferidos encontrarão amparo na tese jurídica do Supremo.

Em outras situações, porém, a improcedência do pedido de ressarcimento pode não estar fundamentada com base no ato culposo e, consequentemente, na tese de repercussão geral. É possível que a negativa ao ressarcimento esteja calcada, pura e simplesmente, na ausência de ato de improbidade. Nestes casos, o pleito autoral será julgado improcedente por inexistir qualquer conduta ímproba do réu. E apenas isso, sequer sendo possível cogitar de aplicação da prescrição, uma vez que a premissa utilizada pelo autor quando da propositura da ação era errônea. Nesta hipótese, portanto, não há aproveitamento da prescrição, que acaba por se tornar um instituto inaplicável à ação de ressarcimento.

De fato, é inconcebível a aplicação da prescrição somente ao final do processo. Por mais que sua declaração evite a condenação do réu pelo ato culposo, são, em muito, diferentes as repercussões de sua aplicação tardia no processo em relação aos momentos iniciais da ação - onde já se demonstrou que o magistrado poderia julgar o feito liminarmente improcedente, de maneira a evitar a discussão do mérito. E as repercussões negativas se dão principalmente pela pecha de ímprobo que recairá sobre o réu.

Restará frustrado o objetivo da ação de ressarcimento, que é justamente a recomposição dos cofres públicos lesados pelo ato de improbidade. Isto porque a tese fixada pelo STF impedirá o ressarcimento caso constatado 0 ato culposo. Contudo, além de não ter atingido o objetivo que almejava, a ação trará uma consequência negativa ao réu: a constatação do ato de improbidade ocorrerá e ser-lhe-á atribuído, ainda que estivesse caracterizada a prescrição, uma vez que esta não evitará a discussão do mérito do caso, em razão de sua declaração posterior.

E a consequência de ter declarado um ato de improbidade contra sua pessoa, que passará a ser tachada de ímproba (ainda que na modalidade culposa), ensejará ao réu a legitimidade recursal para que possa recorrer da sentença, uma vez que lhe impõe gravame ou prejuízo (KOZIKOSKI, 2016, p. 101). Ainda que a aplicação da prescrição "em seu favor" não seja a medida mais gravosa que poderia ser-Ihe aplicada, ainda assim implica exposição. Isto porque a improbidade está conectada à ideia de corrupção e desonra, ${ }^{46}$ é considerada "ilegalidade mais do que especialmente qualificada" (CAMMAROSANO, 2000, p. 273), enquanto, paralelamente, o agente ímprobo é tido como "o devasso da Administração Pública". ${ }^{47}$ Por esta razão, ainda que improcedente a demanda, surgirá ao réu, também, a possibilidade de recorrer da sentença a fim buscar que the seja retirada a imputação de desonesto, de corrupto, de imoral. Ao optar por cindir a incidência da prescrição aos atos culposos de improbidade - pensando estar criando uma benesse ao agente que tenha agido de maneira menos gravosa -, o Supremo Tribunal Federal acabou por inovar no ordenamento jurídico.

Esta inovação é de grande complexidade ao operador e à sistemática do Direito vigente, pois, como visto, desvirtua por completo o instituto da prescrição, retirando-o da lógica de barreira à pretensão processual do autor para que seja empregado como uma consequência do mérito

46 E é justamente por isso que parcela relevante da doutrina pátria não concebe a improbidade na modalidade culposa. Isto pois, se a improbidade é a ilegalidade qualificada pela má-fé, pela intenção de violar os princípios da Administração Pública, como seria possível concebê-la a partir da culpa?

$47 \quad$ Expressão clássica utilizada por José Afonso da Silva (2001, p. 384). 
processual. Tal hermenêutica acaba por desvirtuar o sentido jurídico do instituto jurídico, provocando um indevido rompimento analítico com o sentido da norma constitucional.

\section{CONSIDERAÇÕES FINAIS}

Com o presente trabalho, buscou-se demonstrar que o Supremo Tribunal Federal, ao julgar o Recurso Extraordinário 852.475 (leading case do Tema 897 da Repercussão Geral), acabou por adotar uma decisão que não coaduna com o ordenamento jurídico brasileiro. Trata-se de decisão que desafia os limites do próprio texto da Constituição. Logo, uma decisão inconstitucional.

Inconstitucional porque a Constituição em momento algum prevê que as ações de ressarcimento ao erário serão imprescritíveis. A sua leitura permite afirmar que a prescritibilidade é a regra, enquanto a imprescritibilidade é a exceção, razão pela qual deve constar de maneira taxativa e inequivocamente expressa. Não é o que ocorre na redação do § 5º, do art. 37.

Apegar-se ao termo "ressalvadas", como propugnou o Ministro Fachin, é adotar uma interpretação assistemática, desconsiderando o texto constitucional em sua inteireza - enquanto um sistema - e a particularidade do dispositivo, que, quanto à sua gênese, desejou expurgar a imprescritibilidade.

Não bastasse, consagra um privilégio eterno ao titular da pretensão, o que confronta diversos princípios constitucionais, tais quais a razoabilidade e a simetria. E mais: menospreza o papel da prescrição na consolidação das relações jurídicas e da ordem pública. Ou seja, é uma afronta direta ao princípio da segurança jurídica, prerrogativa não apenas dos eventuais polos da ação de ressarcimento, mas também da sociedade como um todo. Por isso, ainda que formalmente não esteja configurada como tal, no plano material, a imprescritibilidade configura-se como uma sanção ao indivíduo (supostamente) ímprobo. Isto porque a carga aflitiva que recai sobre ele é tão grande que o deixa sem qualquer segurança jurídica, já que poderá ser demandado a qualquer momento pelo ente legitimado que busca o ressarcimento.

Ainda, é inconstitucional porque vai além das possibilidades de exegese do texto. A redação constitucional não permite a conclusão de que a prescrição é aplicável somente aos casos culposos de improbidade administrativa. Não há entrelinhas no texto constitucional que permitam esta conclusão. Refuta-se, portanto, a tese fixada pelo STF de que são imprescritíveis as ações de ressarcimento ao erário. Mais que isso, refuta-se a tese de que é imprescritível o ressarcimento fundado apenas em atos dolosos de improbidade.

Infelizmente, desta inconstitucionalidade que, por si só, já expõe o agente público (e, eventualmente, particulares) ao arbítrio estatal, será possível presenciar outros problemas; agora não no campo hermenêutico, mas no campo processual. Isto porque com a não utilização do rito prescrito pela Lei 8.429/92, há afronta ao direito de defesa do réu, uma vez que não the serão concedidos os instrumentos processuais presentes na lei apropriada. Particularmente, em virtude da desvirtuação da prescrição que, absurdamente, deixa de ser entendida como uma prejudicial da análise de mérito, ficando a este condicionada - o que acaba por prejudicar a racionalidade da decisão tanto no seu viés analítico quanto hermenêutico. 


\section{REFERÊNCIAS}

ABBOUD, Georges e SANTOS, José Carlos Van Cleef de Almeida. Seção III - Do Indeferimento da Petição Inicial. In: ARRUDA ALVIM, Teresa; DIDIER JR., Fredie; TALAMINI, Eduardo; DANTAS, Bruno. Breves comentários ao novo código de processo civil [livro eletrônico]. 3. ed. São Paulo: Revista dos Tribunais, 2016.

ANDRADE, Erico. O controle judicial da responsabilidade fiscal: ação civil pública de improbidade. Jurisprudência Mineira, Belo Horizonte, a. 54, v. 165, jul./set. 2003.

ARAÚJO, Luiz Fernando Diniz. O ativismo judicial e constrangimentos a posteriori. Revista de Investigações Constitucionais, Curitiba, v. 5, n. 1, p. 129-150, jan./abr. 2018.

ASSEMBLEIA NACIONAL CONSTITUINTE. Diário da Assembléia Nacional Constituinte (Ano II n. 203). Brasília: Centro Gráfico do Senado Federal, 1987-1988. Disponível em: http://imagem.camara.gov.br/lmagem/d/pdf/203anc11mar1988.pdf\#page= Acesso em: 12 mar. 2020.

BACELLAR FILHO, Romeu Felipe. Processo Administrativo Disciplinar. 4. ed. São Paulo: Saraiva, 2013.

BACELLAR FILHO, Romeu Felipe; HACHEM, Daniel Wunder. Transferências voluntárias na Lei da Responsabilidade Fiscal: limites à responsabilização pessoal do ordenador de despesas por danos decorrentes da execução de convênio. Interesse Público - IP, Belo Horizonte, ano 12, n. 60, p. 2562, mar./abr. 2010

BANDEIRA DE MELLO, Celso Antônio. Curso de direito administrativo. 34. ed. São Paulo: Malheiros, 2019.

BARBOSA MOREIRA, José Carlos. Questões Prejudiciais e Coisa Julgada. Rio de Janeiro: Borsoi, 1967.

BARROSO, Luís Roberto. A prescrição administrativa no direito brasileiro antes e depois da Lei $\mathrm{n}$. 9873/99. In: Temas de direito constitucional. Rio de Janeiro: Renovar, 2001.

BASTOS, Celso Ribeiro Bastos; e GANDRA MARTINS, Ives. Comentários à Constituição do Brasil: promulgada em 5 de outubro de 1988; v. 3, t. III. São Paulo: Saraiva, 1992.

BEVILÁQUA, Clóvis. Teoria Geral do direito civil. Rio de Janeiro: Paulo de Azevedo Ltda., 1955.

CÂMARA LEAL, Antônio Luiz. Da Prescrição e da Decadência, Rio de Janeiro: Forense, 1978. 
CAMMAROSANO, Márcio. A aplicação do conceito de patrimônio público e sua proteção. In: SUNDFELD, Carlos Ari; BUENO, Cássio Scarpinella (Coords.). Direito Processual Público - A fazenda pública em juízo. São Paulo: Malheiros, 2000.

CARVALHO, Antonio Roberto Winter de. Reflexões acerca da prescritibilidade nas ações de ressarcimento ao erário previstas no art. $37, \S 5$ da constituição. Revista de Direito Administrativo, Rio de Janeiro, v. 253, p. 31-48, jan. 2010.

CARVALHO FILHO, José dos Santos. Improbidade administrativa: prescrição e outros prazos extintivos. 2. ed. rev., atual. e ampl. São Paulo: Atlas, 2016.

COELHO, Fábio Ulhoa. Curso de direito civil [livro eletrônico]: parte geral. v. 1. 1. ed. em e-book baseada na 8. ed. impressa. São Paulo: Revista dos Tribunais, 2016.

COSTA, José Armando da. Contorno jurídico da improbidade administrativa. 3. ed. Brasília: Brasília Jurídica, 2005.

CASTRO, Matheus Felipe de; ZUCCHI, Renan. "Reserva do possível" como argumento de limitação do Estado de Bem-estar social? A Constituição de 1988 e o seu projeto de efetivação dos direitos fundamentais. Revista do Direito, Santa Cruz do Sul, v. 1, n. 57, jul. 2019.

CRETELLA Júnior, José. Comentários à Constituição Brasileira de 1988, v. 4. Rio de Janeiro: Forense Universitária, 1991.

CRUZ, Álvaro Ricardo de Souza; CORREAA, Gustavo Hermont. Ministério Público e o mito do "Peter Pan”. A\&C - Revista de Direito Administrativo \& Constitucional, Belo Horizonte, ano 17, n. 68, abr./jun. 2017.

CRUZ, Luana Pedrosa de Figueiredo. Art. 23. In: GAJARDONI, Fernando da Fonseca; CRUZ, Luana Pedrosa de Figueiredo; CERQUEIRA, Luís Otávio Sequeira de; FAVRETO, Rogério. Comentários à Lei de Improbidade Administrativa: Lei 8.429 de 02 de junho de 1992. 3. ed. São Paulo: Revista dos Tribunais, 2014.

DECOMAIN, Pedro Roberto. Improbidade administrativa. 2. ed. São Paulo: Dialética, 2014.

DIDIER JUNIOR, Fredie. Curso de direito processual civil: introdução ao direito processual civil, parte geral e processo de conhecimento. 17. ed. Salvador: JusPODIVM, v. 1. 2015. 
DINAMARCO, Cândido Rangel; LOPES, Bruno Vasconcellos Carrilho Lopes. Teoria geral do novo processo civil. 3. ed. São Paulo: Malheiros, 2018.

FERREIRA, Sergio de Andrea. Comentários à Constituição, Rio de Janeiro: Biblioteca Jurídica Freitas Bastos, 3ํv. 1991.

FERREIRA, Wolgran Junqueira. Comentários à Constituição de 1988. São Paulo: Julex Livros, v. 1. 1989.

FIGUEIREDO, Marcelo. Probidade administrativa: comentários à Lei 8.429/92 e legislação complementar. 6. ed. São Paulo: Malheiros, 2009.

FORTINI, Cristiana; SHERMAM, Ariane. Corrupção: causas, perspectivas e a discussão sobre o princípio do bis in idem. Revista de Investigações Constitucionais, Curitiba, v. 5, n. 2, p. 91-112, mai./ago. 2018.

GABARDO, Emerson; SAIKALI, Lucas Bossoni. Crítica à decisão do STF sobre a imprescritibilidade do ressarcimento ao erário por atos dolosos de improbidade administrativa. Fórum Administrativo FA, Belo Horizonte, ano 19, n. 223, p. 55-74, set. 2019.

GABARDO, Emerson. Interesse público e subsidiariedade. Belo Horizonte: Fórum, 2009.

GONÇALVES, Luiz da Cunha. Tratado de Direito Civil em comentários ao Código Civil Português. v. 3. São Paulo: Max Limonad, 1955.

GRAU, Eros Roberto. Ensaio e discurso sobre a interpretação/aplicação do direito. 5. ed. São Paulo: Malheiros, 2009.

GRINOVER, Ada Pellegrini. Ação de improbidade administrativa. Decadência e prescrição. Revista da Academia Brasileira de Letras Jurídicas, № 27, p. 37-80, 2007.

GUSSOLI, Felipe Klein. Caça aos ímprobos: como a aplicação da Lei de Improbidade desvinculada das garantias constitucionais desvirtua a finalidade legal. In: BLANCHET, Luiz Alberto; HACHEM, Daniel Wunder; SANTANO, Ana Cláudia. Eficiência e Ética na Administração Pública. Curitiba: Íthala, 2015, p. 243-267.

HARGER, Marcelo. Improbidade administrativa: comentários à Lei no $\mathbf{8 . 4 2 9 / 9 2}$. São Paulo: Atlas, 2015. 
HUMBERT, George Louis Hage. A prescrição na ação de ressarcimento ao erário nas ações de improbidade administrativa: comentários à jurisprudência do STJ. IOB de Direito Administrativo. São Paulo, maio de 2010.

JUSTEN FILHO, Marçal. Curso de Direito Administrativo. 13. ed. rev. atual. e ampl. São Paulo: Thomson Reuters Brasil, 2018.

JUSTEN FILHO, Marçal; GODOY, Miguel Gualano de. A prescritibilidade das ações de ressarcimento ao erário por improbidade: 0 art. 37, § 5ำ da Constituição e o tema 897 da repercussão geral. JOTA, Brasília, p. 01 - 08, 23 abr. 2018. Disponível em: https://www.jota.info/opiniao-eanalise/artigos/prescritibilidade-das-acoes-de-ressarcimento-ao-erario-por-improbidade-23042018 Acesso em: 17 fev. 2020.

KOZIKOSKI, Sandro Marcelo. Sistema Recursal CPC 2015: em conformidade com a Lei 13.256/2016. Salvador: JusPODIVM, 2016.

LIEBMAN, Enrico Tullio. Manual de direito processual civil. Tradução e notas de Cândido R. Dinamarco. Rio de Janeiro: Forense, v. 1. 1984.

YARSHELL, Flávio Luiz; SETOGUTI, Guilherme; RODRIGUES, Viviane Siqueira. MARINONI. Comentários ao Código de Processo Civil: artigos 334 ao 368. In: MARINONI, Luiz Guilherme; ARENHART, Sérgio Cruz; MITIDIERO, Daniel. Coleção comentários ao Código de Processo Civil; v. 5. São Paulo: Revista dos Tribunais, 2016.

MARINONI, Luiz Guilherme; ARENHART, Sérgio Cruz; MITIDIERO, Daniel. Novo curso de processo civil: tutela dos direitos mediante procedimento comum, 5. ed. ampl. São Paulo: Revista dos Tribunais, v. 2. 2019.

MARINONI, Luiz Guilherme; MITIDIERO, Daniel. Direitos fundamentais processuais. In: SARLET, Ingo; MARINONI, Luiz Guilherme; e MITIDIERO, Daniel. Curso de direito constitucional. 4. ed. ampl., incluindo novo capítulo sobre princípios fundamentais. São Paulo: Saraiva, 2015.

MARTINS, Ricardo Marcondes. Improbidade administrativa e inversão do ônus da prova. A\&C Revista de Direito Administrativo \& Constitucional, Belo Horizonte, ano 10, n. 42, out./dez. 2010.

MENDES, Gilmar Ferreira; BRANCO, Paulo Gustavo Gonet. Curso de direito constitucional. 14. ed. rev. e atual. São Paulo: Saraiva Educação, 2019.

MEZZOMO, Marcelo Colombelli. A imprescritibilidade das ações ressarcitórias recorrentes de atos de improbidade administrativa: Um equívoco hermenêutico. Âmbito Jurídico, Rio Grande, III, n. 10, ago. 
http://www.ambitojuridico.com.br/site/index.php?n_link=revista_artigos_leitura\&artigo_id=4699 Acesso em: 17 fev. 2020.

NERY JUNIOR, Nelson; e NERY, Rosa Maria de Andrade. Constituição Federal comentada e legislação constitucional [livro eletrônico]. 2. ed. São Paulo: Revista dos Tribunais, 2016.

NEVES, Daniel Amorim Assumpção; OLIVEIRA, Rafael Carvalho Rezende. Manual de Improbidade Administrativa: direito material e processual. 7. ed. São Paulo: Método, 2019.

NOBRE JÚNIOR, Edilson Pereira. Jurisdição constitucional e política. Revista de Investigações Constitucionais, Curitiba, v. 4, n. 2, p. 147-162, maio/ago. 2017.

OSÓRIO, Fábio Medina. Direito administrativo sancionador. 5. ed. São Paulo: Revista dos Tribunais, 2015.

PAZZAGLINI FILHO, Marino. Lei de improbidade administrativa comentada: aspectos constitucionais, administrativos, civis, criminais, processuais e de responsabilidade fiscal. 7 . ed. São Paulo: Atlas, 2018.

PINHO, Clóvis Alberto Bertolini de. Corrupção e administração pública no Brasil: combate administrativo e a Lei o 12.846/2013 (Lei Anticorrupção). São Paulo: Almedina, 2020.

PONTES DE MIRANDA, Francisco Cavalcanti. Tratado de direito privado. t. VI. 4. ed. São Paulo: Revista dos Tribunais, 1974.

RIZZARDO, Arnaldo. Ação civil pública e ação de improbidade administrativa. 3. ed. rev., atual. e ampl. Rio de Janeiro: Forense, 2014.

RODRÍGUEZ-ARANA MUÑOZ, Jaime. Caraterización constitucional de la ética pública (Especial referencia al marco constitucional español). Revista de Investigações Constitucionais, Curitiba, vol. 1, n. 1, p. 67-80, jan./abr. 2014.

SARLET, Ingo; MARINONI, Luiz Guilherme; MITIDIERO, Daniel. Curso de direito constitucional. 4. ed. ampl., incluindo novo capítulo sobre princípios fundamentais. São Paulo: Saraiva, 2015.

SILVA, José Afonso da. Curso de direito constitucional positivo. 21 ed. São Paulo: Malheiros, 2001. 
SILVA, Willy Potrich da; FREIRE JÚNIOR, Américo Bedê. Analítica e hermenêutica: duas faces de uma mesma solução para a garantia da racionalidade na aplicação do direito. Revista do Direito, Santa Cruz do Sul, v. 1, n. 57, jul. 2019.

SIMÃO, Calil. Improbidade administrativa: teoria e prática. 3. ed. Belo Horizonte: Editora J.H. Mizuno, 2017.

STF. Supremo Tribunal Federal. Recurso Extraordinário n. RE 852475/SP, Relator Min. Alexandre De Moraes, Relator para o Acórdão Min. Edson Fachin, Tribunal Pleno, Julgado em 08/08/2018, Processo Eletrônico de Repercussão Geral, Publicado no Diário de Justiça Eletrônico do STF n. 58, em $25 \quad$ mar. 2019.2 Disponível em: http://redir.stf.jus.br/paginadorpub/paginador.jsp?docTP=TP\&doclD=749427786. Acesso em: 25 fev. 2020.

SUNDFELD, Carlos Ari; SOUZA, Rodrigo Pagani de. A prescrição das ações de ressarcimento ao Estado e 0 art. 37, $\S 5^{\circ}$ da Constituição. A\&C - Revista de Direito Administrativo \& Constitucional. Belo Horizonte, ano 17, n. 68, p. 139-152, abr./jun. 2017.

THEODORO JÚNIOR, Humberto. Curso de Direito Processual Civil - Teoria geral do direito processual civil, processo de conhecimento e procedimento comum. 57. ed. rev., atual. e ampl. Rio de Janeiro: Forense, v. I. 2016.

TOURINHO, Rita. Discricionariedade Administrativa, ação de improbidade \& controle principiológico. 2. ed. Curitiba: Juruá, 2009.

WAMBIER, Luiz Rodrigues; TALAMINI, Eduardo. Curso avançado de processo civil: cognição jurisdicional (processo comum de conhecimento e tutela provisória), 16. ed. reformulada e ampliada de acordo com o novo CPC. São Paulo: Revista dos Tribunais, v. 2. 2016.

ZAVASCKI, Teori Albino. Processo coletivo: tutela de direitos coletivos e tutela coletiva de direitos. 6. ed. rev., atual. e ampl. São Paulo: Revista dos Tribunais, 2014. 